\title{
Thermal Effect on Aequorea Green Fluorescent Protein Anionic and Neutral Chromophore Forms Fluorescence
}

\author{
Andrea Martins dos Santos
}

Received: 13 March 2011 / Accepted: 28 July 2011 /Published online: 10 August 2011

(C) Springer Science+Business Media, LLC 2011

\begin{abstract}
The emission behaviour of Aequorea green fluorescent protein (A-GFP) chromophore, in both neutral (N) and anionic (A) form, was studied in the temperature range from $20{ }^{\circ} \mathrm{C}$ to $75{ }^{\circ} \mathrm{C}$ and at $\mathrm{pH}=7$. Excitation wavelengths of $399 \mathrm{~nm}$ and $476 \mathrm{~nm}$ were applied to probe the $\mathrm{N}$ and $\mathrm{A}$ forms environment, respectively. Both forms exhibit distinct fluorescence patterns at high temperature values. The emission quenching rate, following a temperature increase, is higher for the chromophore $\mathrm{N}$ form as a result of the hydrogen bond network weakening. The chromophore anionic form emission maximum is red shifted, upon temperature increase, due to a charge transfer process occurring after A form excitation.
\end{abstract}

Keywords Green fluorescent protein · Chromophore . Fluorescence · Temperature

$\begin{array}{ll}\text { Abbreviations } \\ \text { BCA } & \text { Bicinchoninic acid } \\ \text { ESPT } & \text { Excited-state proton transfer } \\ \text { FPLC } & \text { Fast protein liquid chromatography } \\ \text { GFP } & \text { Green fluorescent protein } \\ \text { Gly } & \text { Glycine }\end{array}$

A. M. dos Santos

IN-CQFM, Instituto Superior Técnico,

Universidade Técnica de Lisboa,

Av. Rovisco Pais,

1049-001 Lisbon, Portugal

Present Address:

A. M. dos Santos $(\bowtie)$

Biomembranes Unit, Instituto de Medicina Molecular,

Faculdade de Medicina, Universidade de Lisboa,

Av. Professor Egas Moniz,

1649-028 Lisbon, Portugal

e-mail: andreasantos@fm.ul.pt

$\begin{array}{ll}\text { His } & \text { Histidine } \\ \text { IPTG } & \text { Isopropyl } \beta \text {-D-1-thiogalactopyranoside } \\ \text { LB } & \text { Luria-Bertani } \\ \text { Ser } & \text { Serine } \\ \text { SDS-PAGE } & \begin{array}{l}\text { Sodium dodecyl sulfate-polyacrylamide gel } \\ \text { electrophoresis }\end{array} \\ \text { Trp } & \text { Tryptophan } \\ \text { Tyr } & \text { Tyrosine }\end{array}$

\section{Introduction}

Since its discovery in the early $60 \mathrm{~s}$, several structural derivatives of the green fluorescent protein (GFP) have already been registered in the Protein Data Bank (http:// www.pdb.org/), and their physico-chemical properties are rather well described in the literature [1-5]. The wild type AGFP protein from the bioluminescent jellyfish Aequorea victoria, has 238 amino acid residues, a molecular weight (MW) of $26.9 \mathrm{kDa}$ and a theoretical isoelectric point (pI) of 5.8 (from ExPASy). Its X-ray barrel-type structure was resolved at $1.85 \AA$ (PDB entry: $1 \mathrm{~W} 7 \mathrm{~S}$; [6]), and is formed by eleven $\beta$-sheets and one $\alpha$-helix, to which the GFP chromophore is connected. The latter is obtained by a posttranslational cyclization reaction of the polypeptide skeleton Ser65, Tyr66 and Gly67 residues, followed by oxidation of the Tyr66 residue lateral side-chain [7-9]. Through a hydrogen bonds network involving particular polar residues and $\mathrm{H}_{2} \mathrm{O}$ molecules, the cromophore is able to establish noncovalent interactions with the protein $[10,11]$. From a structural point of view, the protein is highly regular although an exception to this overall behaviour can be observed between strands 7 and 8 of the $\beta$-barrel $[12,13]$, whose termini is formed by small sections of the $\alpha$-helix that resemble "lids". 
Regarding its photophysics, the wild type GFP protein is characterized by high quantum yields, $\phi_{f} \sim 0.8$, in contrast to what is observed for its individual cromophore in aqueous solution, $\phi_{f} \sim 10^{-3}[14,15]$. In the native fold, the inhibition of molecular vibration or rotation along the chromophore double exo-metilene bond, prevents emission quenching by a rapid internal conversion process $[13,15,16]$. Inside the $\beta$-barrel, chromophore's fluorescence extinction by $\mathrm{O}_{2}$ [17] and by hydron ions [18] is also avoid.

Most of the GFP structural events reported in the literature have been studied below room temperature. However, several applications of GFP under physiological conditions (e.g. $\mathrm{T}=20-40{ }^{\circ} \mathrm{C}, \mathrm{pH}=6-8$ ) have recently been proposed, in domains like cell biology and biotechnology. Namely, in GFP-fused proteins folding [19] and enzyme activity [20] assays, and as a biological indicator in thermal processes [21]. In face of these previous observations, it's clear that a thorough and systematic study of the photophysical properties of GFP is of the utmost relevance, and needs to address distinct medium conditions (e.g. temperature, $\mathrm{pH}$, ionic force). It is the purpose of this work to contribute for the latter, performing accurate measurements of the A-GFP excitation and emission spectra in the temperature range between $20{ }^{\circ} \mathrm{C}$ and $75{ }^{\circ} \mathrm{C}$ and $\mathrm{pH}=7$ (phosphate buffer), and therefore accessing the influence of temperature on A-GFP photophysical properties. The results obtained are interpreted and discussed in terms of structural features and photophysical behaviour taking into account the most recent findings on this matter.

\section{Materials and Methods}

\section{Protein Expression and Purification}

The His-tagged wild type A-GFP protein was expressed in E. Coli BL21 competent cells using the plasmid pRSETa containing its gene. Cells were grown at $37{ }^{\circ} \mathrm{C}$ in Luria-Bertani (LB) broth with $100 \mathrm{mg} / \mathrm{ml}$ ampicillin. The cultures were induced by addition of $1 \mathrm{M}$ isopropyl $\beta$-D-1-thiogalactopyranoside (IPTG) and grown for $\sim 9 \mathrm{~h}$, at $28{ }^{\circ} \mathrm{C}$. The cells were harvested by centrifugation and resuspended in phosphate buffer at $\mathrm{pH}$ 8. Cells lysis was performed by sonication and the resultant crude extract centrifuged to remove cell debris. The recombinant protein with a six-His tag was purified using a Ni-NTAagarose affinity column (from Qiagen) and Fast Protein Liquid Chromatography (FPLC; from Pharmacia). In addition, the protein was dialysed against $10 \mathrm{mM}$ phosphate buffer $(\mathrm{pH} 7)$ and stored at $-18{ }^{\circ} \mathrm{C}$. Protein purity was confirmed by sodium dodecyl sulfate-polyacrylamide gel electrophoresis (SDS-PAGE), from where the molecular weight $\mathrm{MW} \sim 27 \mathrm{kDa}$, was recovered. Protein con- centration was estimated by bicinchoninic acid (BCA) assay [22].

\section{Fluorescence Measurements}

Fluorescence spectra were recorded in a spectrofluorimeter Fluorolog F112A (from Spex) by excitation at $\lambda_{\text {exc }}=399 \mathrm{~nm}$ or $\lambda_{\text {exc }}=475 \mathrm{~nm}$. Excitation spectra were obtained at $\lambda_{\mathrm{em}}=$ $506 \mathrm{~nm}$. The recorded spectra were corrected for Raman scattering, and detecting system response using a correction curve previously determined for the equipment. The temperature was varied between $20^{\circ} \mathrm{C}$ and $75{ }^{\circ} \mathrm{C}$, with an estimated accuracy of $\pm 0.5{ }^{\circ} \mathrm{C}$, and the solutions were stirred during the measurements. All spectroscopic measurements were carried out with $0.1 \mu \mathrm{M}$ protein dissolved in $10 \mathrm{mM}$ phosphate buffer at $\mathrm{pH}=7$.

\section{Results and Discussion}

The excitation spectra of A-GFP solutions $(0.1 \mu \mathrm{M}, \mathrm{pH}=7)$ are illustrated in Fig. 1, and were obtained using an emission wavelength of $\lambda_{e m}=506 \mathrm{~nm}$.

The bands visible at $400 \mathrm{~nm}$ and $476 \mathrm{~nm}$ are usually associated with the chromophore protonation states neutral (N) and anionic (A), respectively [15, 23]. The excitation band at $278 \mathrm{~nm}$ is due to nonspecific, more energetic electronic transitions occurring in the chromophore. At $\mathrm{pH}$ 7 and room temperature, the chromophore neutral form is the dominant one. As temperature is increased from $20^{\circ} \mathrm{C}$ to $75^{\circ} \mathrm{C}$, both bands at $400 \mathrm{~nm}$ (form N) and $476 \mathrm{~nm}$ (form A) decrease their intensity, and this trend is enhanced for the neutral form; above $60^{\circ} \mathrm{C}$ the excitation spectra become identical, and it can be concluded that beyond that threshold temperature no longer influences the chromophore photo-

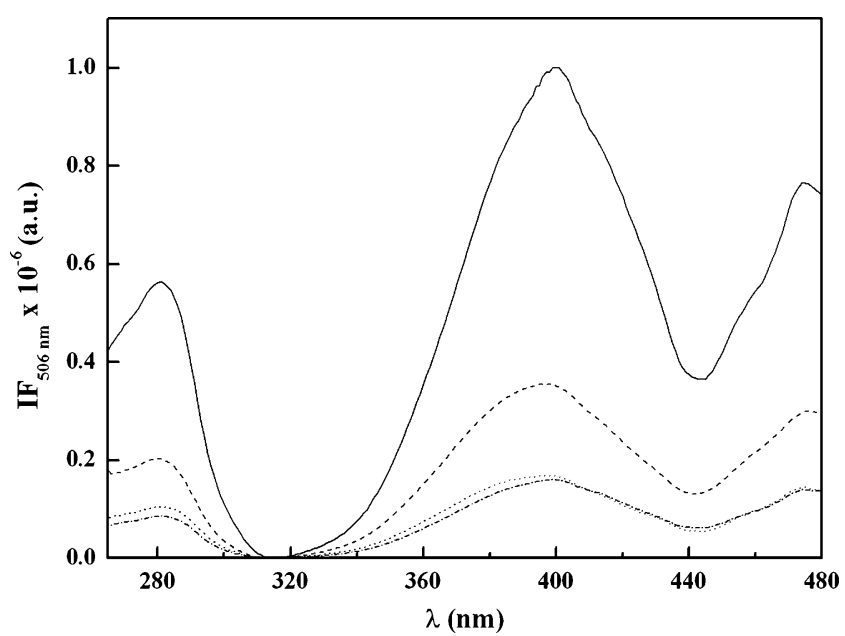

Fig. 1 Excitation spectra of A-GFP solution $(0.1 \mu \mathrm{M}, \mathrm{pH}=7), \lambda_{\text {em }}=$ $506 \mathrm{~nm}$ : (-) $20{ }^{\circ} \mathrm{C},(--) 60{ }^{\circ} \mathrm{C},(-\cdots) 65{ }^{\circ} \mathrm{C},(\cdots) 70{ }^{\circ} \mathrm{C}$ 
physics. The blue shift occurring in the neutral form peak, from $400 \mathrm{~nm}$ to $396 \mathrm{~nm}$, suggests the occurrence of a more energetic electronic transition as temperature is increased.

The emission spectra obtained by excitation at $399 \mathrm{~nm}$ and $475 \mathrm{~nm}$, in the temperature range between $20^{\circ} \mathrm{C}$ and $75^{\circ} \mathrm{C}(\mathrm{pH}=7)$, are recorded in Figs. 2 and 3, respectively. The chromophore neutral form selective excitation at $399 \mathrm{~nm}$ gives origin to the green fluorescence with maximum at $511 \mathrm{~nm}$ (see Fig. 2). This emission results from the excited neutral species $\left(\mathrm{N}^{*}\right)$ deprotonation forming an excited intermediary $\left(\mathrm{I}^{*}\right)$, as described by Chattoraj et al. [24]; the excited-state proton transfer (ESPT) should occur via the hydrogen-bond network from cromophore to Glu222 residue, as reported by Laino et al. [25].

When temperature is increased to $60{ }^{\circ} \mathrm{C}$, it is very interesting to observe that the band at $511 \mathrm{~nm}$ markedly decreases its intensity (Fig. 2), and this fact can be mainly ascertained to the weakening of the hydrogen-bond network. Consequently, the ESPT process occurring via hydrogen-bond network is progressively deactivated thus quenching the emission from $\mathrm{I}^{*}$. Above $60{ }^{\circ} \mathrm{C}$, the protein unfolds and its cromophore is released from its static environment and exposed to the solvent. The intrinsic nonradiative and dynamic events become more important,

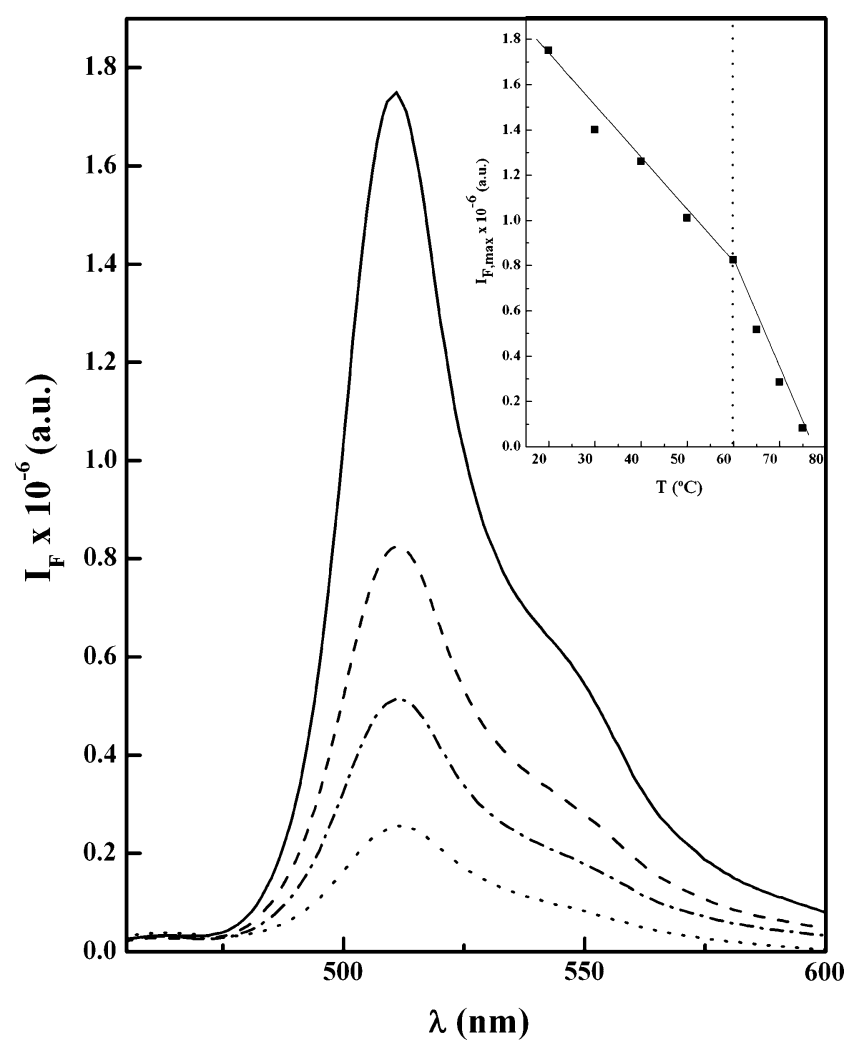

Fig. 2 Emission spectra of A-GFP solution $(0.1 \mu \mathrm{M}, \mathrm{pH}=7), \lambda_{\text {exc }}=$ 399 nm: (-) $20{ }^{\circ} \mathrm{C}$, (- -) $60{ }^{\circ} \mathrm{C},(-\cdots) 65{ }^{\circ} \mathrm{C},(\cdots) .70{ }^{\circ} \mathrm{C}$. Insert: Emission maxima variation with temperature increase

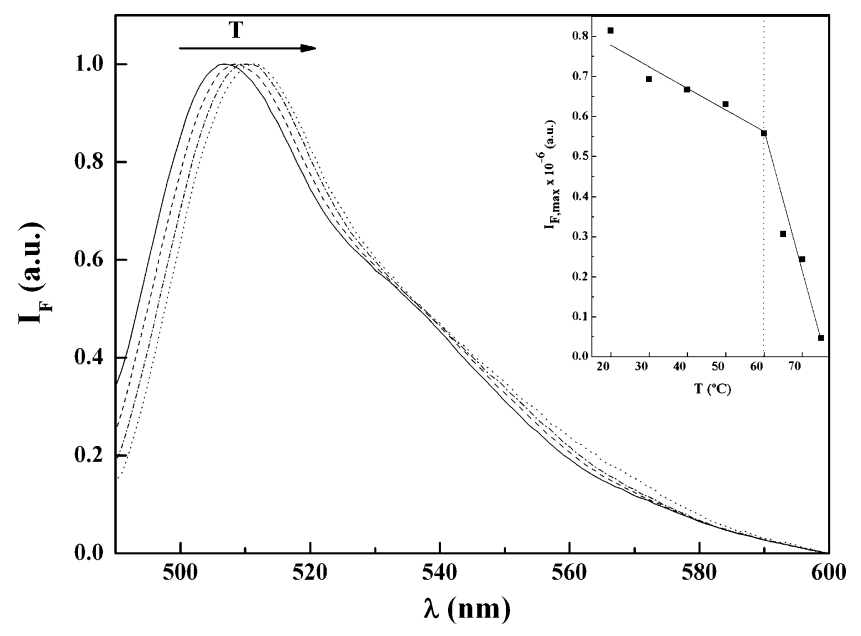

Fig. 3 Normalized emission spectra of A-GFP solution $(0.1 \mu \mathrm{M}, \mathrm{pH}=7)$, $\lambda_{\text {exc }}=475 \mathrm{~nm}$ : (-) $20{ }^{\circ} \mathrm{C}$, (- -) $40^{\circ} \mathrm{C},(-\cdot-) 60{ }^{\circ} \mathrm{C},(\cdots \cdot) 70{ }^{\circ} \mathrm{C}$. Insert: Emission maxima variation with temperature increase

highly reducing the cromophore fluorescence intensity. Here, the most probable $\mathrm{N}^{*}$ species decay channels are the weak and featureless emission from state $S_{1}$ to state $S_{0}$ at $460 \mathrm{~nm}$, and the non-radiative decay through rotation along one of the ring-bridging bonds.

The cromophore anionic form emission spectrum, obtained by excitation at $475 \mathrm{~nm}$ (Fig. 3), exhibits a blue shifted emission band with maximum at $507 \mathrm{~nm}$, when compared with the corresponding neutral form emission spectrum.

It can also be observed in Fig. 3 that, upon temperature increase the anionic form emission maximum is shifted to the red by roughly $6 \mathrm{~nm}$, resulting from cromophore solvent exposure during protein unfolding. Upon excitation, the anionic species dipolar moment changes by $\Delta \mu \approx 6.8 \mathrm{D}$. The dipolar moment variation, not observed in the neutral form, results from a charge density transfer occurring between the close neighbours $(\sim 9 \AA)$ oxygen atoms located on the phenolic and imidazolinone rings $[24,26]$. This dipolar change is responsible for the solvent molecules reorganization around the anionic form electronic excited state decreasing its energy. It should be noted that this phenomenon is more visible for solvent exposed chromophore molecules and leads to the observed red shift. The emission intensity decrease upon temperature increase is due to the enhancement of dynamic quenching processes, but also to the prevalence of non-radiative decay through a hula-twist rotation above $60{ }^{\circ} \mathrm{C}$.

The A-GFP chromophore emission is highly quenched by temperature increase and this effect is twice more pronounced on its neutral form before unfolding (see inserts on Figs. 2 and 3). Opposite to the A* decay, the $\mathrm{N}^{*}$ decay occurs mainly via an ESPT process involving the hydrogen-bond network. Following a temperature increase this mechanism is progressively deactivated due to the 
network breakage, causing the accentuated decrease on the chromophore neutral form emission.

The emission maximum break, observed at $60{ }^{\circ} \mathrm{C}$ for both $\mathrm{N}$ and $\mathrm{A}$ forms (see inserts on Figs. 2 and 3), reflects the temperature induced protein unfolding. The melting temperature value determined here of $60{ }^{\circ} \mathrm{C}$ is smaller than $T \approx 78^{\circ} \mathrm{C}$, observed for the A-GFP (at $\mathrm{pH}=7$ ) by Ward et al. [27]. Above $60{ }^{\circ} \mathrm{C}$ the A-GFP structure collapses and its emission rapidly decreases due to the accentuation of intrinsic non-radiative and dynamic quenching events.

\section{Conclusions}

The hydrogen bond network weakening, caused by a temperature increase up to $75{ }^{\circ} \mathrm{C}$, is responsible for the ESPT process deactivation at higher temperature values. This event is particularly relevant in the excited neutral form decay via deprotonation and conversion to the intermediary $\mathrm{I}^{*}$, leading to a pronounced fluorescence quenching of the later. Regarding the anionic form, due to the occurrence of charge density transfer after excitation, its fluorescence maximum is progressively red shifted upon temperature increase. Above $60{ }^{\circ} \mathrm{C}$ the protein unfolds, exposing its chromophore to the solvent. Consequentially, the intrinsic non-radiative and dynamic quenching decay events become predominant, highly reducing chromophore both forms fluorescence intensity.

Acknowledgments The author acknowledges financial support from Fundação para a Ciência e a Tecnologia through grant SFRH/BPD/ $26821 / 2006$, Dr. V. Subramanian (University of Twente, NL) for providing the A-GFP gene, and Dr. F. Mergulhão (University of Porto, PT) for the support given on A-GFP expression and purification.

\section{References}

1. Chalfie M, Kain S (2006) Green fluorescent protein: properties, applications and protocols, vol 47. John Wiley \& Sons, Inc

2. Conn PM (1999) Green fluorescent protein, vol 302. Academic, San Diego

3. Sullivan KF, Kay SA (1998) Green fluorescent protein: methods in cell biology, vol 58. Academic, San Diego

4. Tsien RY (1998) The green fluorescent protein. Annu Rev Biochem 67:509-544

5. Sanders JKM, Jackson SE (Eds) (2009) Green fluorescent protein. Chem Soc Rev 38:2813-2968

6. Thor JJ, Georgiev GY, Towrie M, Sage JT (2005) Ultrafast and low barrier motions in the photoreactions of the green fluorescent protein. J Biol Chem 280:33652-33659

7. Prasher DC, Eckenrode VK, Ward WW, Prendergast FG, Cormier MJ (1992) Primary structure of the Aequorea victoria greenfluorescent protein. Gene 111:229-233
8. Cody CW, Prasher DC, Westler WM, Prendergast FG, Ward WW (1993) Chemical structure of the hexapeptide chromophore of the Aequorea green-fluorescent protein. Biochemistry 32:1212-1218

9. Heim R, Prasher DC, Tsien RY (1994) Wavelength mutations and posttranslational autoxidation of green fluorescent protein. Proc Natl Acad Sci USA 91:12501-12504

10. Ormö M, Cubitt AB, Kallio K, Gross LA, Tsien RY, Remington SJ (1996) Crystal Structure of the Aequorea victoria Green Fluorescent Protein. Science 273:1392-1395

11. Brejc K, Sixma TK, Kitts PA, Kain SR, Tsien RY, Ormö M (1997) Structural basis for dual excitation and photoisomerization of the Aequorea victoria green fluorescent protein. Proc Natl Acad Sci USA 94:2306-2311

12. Helms V, Straatsma TP, McCammon JA (1999) Internal dynamics of green fluorescent protein. J Phys Chem B 103:3263-3269

13. Phillips GNJ (1997) Structure and dynamics of green fluorescent protein. Curr Opin Struct Biol 7:821-827

14. Morise H, Shimomura O, Johnson FH, Winant J (1974) Intermolecular energy transfer in the bioluminescent system of Aequorea. Biochemistry 13:2656-2662

15. Niwa $H$, Inouye $S$, Hirano $T$, Matsuno $T$, Kojima M, Kubota M, Ohashi M, Tsuji FI (1996) Chemical nature of the light emitter of the Aequorea green fluorescent protein. Proc Natl Acad Sci USA 93:13617-13622

16. Kummer AD, Kompa C, Lossau H, Poellinger DF, Michel BM, Silva CM, Bylina EJ, Coleman WJ, Yang MM, Youvan DC (1998) Dramatic reduction in fluorescence quantum yield in mutants of Green Fluorescent Protein due to fast internal conversion. Chem Phys 237:183-193

17. Rao BD, Kemple MD, Pendergast FG (1980) Proton nuclear magnetic resonance and fluorescence spectroscopic studies of segmental mobility in aequorin and a green fluorescent protein from Aequorea forskalea. Biophys J 32:630-632

18. Ward WW, Bokman SH (1982) Reversible denaturation of Aequorea green-fluorescent protein: physical separation and characterization of the renatured protein. Biochemistry 21:4535-4540

19. de Groot N, Ventura S (2006) Effect of temperature on protein quality in bacterial inclusion bodies. FEBS Lett 580:6471-6476

20. Zhang C, Liu MS, Xing XH (2009) Temperature influence on fluorescence intensity and enzyme activity of the fusion protein of GFP and hyperthermophilic xylanase. Appl Microbiol Biotechnol 84:511-517

21. Ishii M, Kunimura JS, Penna T, Cholewa O (2007) Study on the thermal stability of green fluorescent protein (GFP) in glucose parenteral formulations. Int J Pharm 337:109-117

22. Stoscheck CM (1990) Quantitation of protein. Methods Enzymol 182:50-69

23. Creemers TMH, Lock AJ, Subramaniam V, Jovin TM, Volker S (1999) Three photoconvertible forms of green fluorescent protein identified by spectral hole-burning. Nat Struct Biol 6:557-560

24. Chattoraj M, King BA, Bublitz GU, Boxer SG (1996) Ultra-fast excited state dynamics in green fluorescent protein: multiple states and proton transfer. Proc Natl Acad Sci USA 93:8362-8367

25. Laino T, Nifosì R, Tozzini V (2004) Relationship between structure and optical properties in green fluorescent proteins: a quantum mechanical study of the chromophore environment. Chem Phys 298:17-28

26. Bublitz G, King BA, Boxer SG (1998) Electronic structure of the chromophore in green fluorescent protein (GFP). J Am Chem Soc 120:9370-9371

27. Ward WW, Prentice HJ, Roth AF, Cody CW, Reeves SC (1982) Spectral perturbations of the Aequorea green-fluorescent protein. Photochem Photobiol 35:803-808 